\title{
ETHIOPIAN LAW OF INTERNATIONAL CARRIAGE BY AIR: AN OVERVIEW
}

Hailegabriel G. Feyissa *

\begin{abstract}
Ethiopia's aviation history goes back to the late 1920s. And, carriage of goods and passengers by air dates at least as far back as the 1940s - the decade which witnessed the establishment of Ethiopian Air Lines Corporation (now Ethiopian Airlines). Despite Ethiopia's relative success in commercial aviation, domestic literature on commercial air law has been scanty. Court decisions involving air carriage are rare, and one can seldom find a course on air law in the curricula of Ethiopian law schools. This article is an attempt to briefly address the gap in literature and encourage further academic discourse on Ethiopian law of air carriage with particular attention to the law and practice regarding international carriage by air.
\end{abstract}

\section{Key words:}

Air law, international carriage by air, the 1929 Warsaw Convention, liability of the carrier, documents of carriage, limitation of liability of the carrier

DOI

http://dx.doi.org/10.4314/mlr.v5i2.2

\section{Introduction}

The law on carriage by air forms part of air law (civil aviation law). ${ }^{1}$ It is that part of air law governing the liability of air carrier under contract of air carriage. $^{2}$ Historically, it dates only as far back as the early $20^{\text {th }}$ century when aerial navigation began the transition from myth to reality. ${ }^{3}$ Though domestic

* Lecturer in Law (Bahir Dar University) and Attorney at Law (ANRS); LLB (Bahir Dar University, Ethiopia); LLM in International Economic and Business Law (University of Groningen, the Netherlands). The author can be reached at $<$ hailegabrielfeyissa@gmail.com>.

${ }^{1}$ Air law may be defined "part of law relating to civil aviation." It deals with range of aviation matters including, but not limited to, registration of aircraft, aviation safety, movement of aircraft across airspace, provision of aeronautical services, aviation crime, and carriage by air. Air law can be interchangeably used with aviation law; see Benyam T. \& Hailegabriel G. (2010), International Air \& Space Law Module. Bahir Dar, Bahir Dar University, p. 3.

${ }^{2}$ Accordingly, it determines the basis of the carrier's liability, the limits of liability, and other related matters such as contents and forms of travel documents, jurisdiction and limitation of liability.

${ }^{3}$ See, e.g., Hudson, M. (1930) "Aviation and International Law," The American Journal of International Law, (24), p.229-230 [hereinafter Hudson]; In contrast, the law on sea 
legislations on private and public air law had already existed even before the $20^{\text {th }}$ century, ${ }^{4}$ discussions regarding carriage by air began ${ }^{5}$ since the $1900 \mathrm{~s}$ - the decade which saw the Wright Brothers (Orville and Wilbur Right) successfully carry out "the first controlled powered flight of airplane.",

Air law in general and the law on carriage by air in particular developed mainly within an international context. ${ }^{7}$ The initial efforts to codify the law on international carriage by air were facilitated by Comité Juridique International de l'Aviation which in 1911 drafted a code of air law. ${ }^{8}$ Further, it conducted two diplomatic conferences the second of which was held in Warsaw, Poland where numerous states gathered to consider a draft convention prepared by a committee of experts drawn from different countries. Agreement was eventually reached over a convention which became the Convention for the Unification of Certain Rules relating to International Carriage by Air (the 1929 Warsaw Convention).

Ethiopia was not among the original signatories to the Warsaw Convention. Ethiopia started its aviation history a few years after the Warsaw Convention was signed. ${ }^{9}$ However, it took steps in ratifying and subsequently giving effect

carriage dates as far back as 900 B.C; see, e.g. Hailegabriel, G. (2008) Maritime Law Teaching Material. Addis Ababa, JLSRI, p.12.

${ }^{4}$ Laws regulating balloon flights were in place in, for example, France during the $18^{\text {th }}$ century; see Diederiks-Verschoor, I. (2001) An Introduction to Air Law. The Hague, Kluwer Law International, p.2 [hereinafter Diederiks -Verschoor]

5 See, e.g., Kuhn, A. (1910) "The Beginnings of An Aerial Law," American Journal of International Law, (4), p.109 et seq.; Baldwin, S. (1910) "The Law of the Airship," American Journal of International Law, (4), 95 et seq.

6 Jordan, T. (1953-1954) "Aviation, Past and Present," The Wisconsin Magazine of History, (37), p.79 [hereinafter Jordan]; Tuan, K. (1965) "Aviation Insurance in America," The Journal of Risk and Insurance, (32), pp. 1-2[hereinafter Tuan]; within less than two decades of the 1903 Wright Brothers' attempted flight, airplanes began to be used for passenger and cargo transportation. By late 1910s and early 1920s, there had already been some commercial flights in the US and Europe. Historical records show Ethiopia did not wait long before joining the aviation world. Before the Italian Occupation (1936-1941), domestic routes were opened to, for instance, to Bishoftu (see note 9 infra); see, e.g. Jordan, p.80; Tuan, p.2; Diederiks-Verschoor, supra note 4, p.2.

${ }^{7}$ In this regard, the role of the Institute of International Law, which was engaged in the study of the law governing aviation since 1900, is worth considering; see generally Hudson, pp. 228-240; Diederiks-Verschoor, supra note 4, p.2-8; Philipson, G. \& et al. (2001) Carriage by Air. London, Butterworths, § $1.1-1.54$ [hereinafter Philipson].

${ }^{8}$ Ibid, Philipson, § $1.4-1.5$.

${ }^{9}$ The year 1929 witnessed the arrival in Ethiopia of a French aircraft. Interestingly, the years preceding the Italian Occupation showed developments in the use of civil 
to the Convention in 1950, some four years after the incorporation of Ethiopian Air Lines as subsidiary of TWA (Trans World Airlines). ${ }^{10}$ This makes Ethiopia the first African ${ }^{11}$ state to join the Convention.

In 1960, Ethiopia enacted a Commercial Code. Book III, Title II of the 1960 Commercial Code ${ }^{12}$ contains rules applicable to air carriage. These rules show huge resemblance to the 1929 Warsaw Convention. ${ }^{13}$ Since 1960, Ethiopia has thus had two separate laws for carriage by air. While the Warsaw Convention applied to "international carriage", the Commercial Code must have applied in the domain of domestic carriage. ${ }^{14}$ As of 2008, however, the Ethiopian law on carriage by air has basically been consolidated. At present, the Civil Aviation Proclamation ${ }^{15}$ provides that "the liability of any air carrier to passengers and cargo is governed by the rules and limitations contained in the international legal instruments to which Ethiopia is a party." ${ }^{16}$ It can now be argued that the provisions of the Commercial Code on carriage by air are superseded by their counterpart provisions embodied under international legal instruments to which Ethiopia is a party.

aviation. Aircrafts were purchased; domestic routes and aviation schools were opened (see "The History of Aviation in Ethiopia" at <www.ecaa.gov.et> [last accessed December 23, 2010]); see also Bahiru, Zewde (2011) "Ethiopia's Entry into the Jet Age," Selamata, (28), p.54.

${ }^{10}$ Jandy, E. (1956) "Ethiopia Today: A Review of Its Changes and Problems," Annals of the American Academy of Political and Social Science, (306), p. 115.

${ }^{11}$ Though the Republic of South Africa signed the Convention in 1929, it was only in 1954 that it took steps in ratifying the Convention. In contrast, Ethiopia signed and ratified the Convention in 1950, making it the first African nation to give force to the Convention; see $<$ http://www.icao.int/icao/en/leb/wc-hp.pdf $>$.

12 Commercial Code of Ethiopia, 1960, Negarit Gazeta, Proclamation No. 166/1960, 19th Year, No.3 [hereinafter Commercial Code].

13 Yet, the Commercial Code benefited from amendments to the original Warsaw Convention. For instance, Article 609(2) Commercial does not, unlike Article 4(3) of Warsaw Convention, sanction the delivery of baggage check that does not contain the number of passenger ticket and the number and weight of the packages. See note 92 infra.

${ }^{14}$ See, for example, Negist Makonnen et al. $v$ Ethiopian Airlines et al. (Addis Ababa High Court Civil Case No. 701/55 E.C [reported in Journal of Ethiopian Law Vo. 3(1), pp. 68-74]) where the Addis Ababa High Court maintained that the Warsaw Convention cannot apply to domestic carriage with respect to which the Commercial Code applied; see also further discussions under 2.1.

${ }^{15}$ Civil Aviation Proclamation, 2008, Federal Negarit Gazeta, Proclamation No. 616, Year 15, No. 23 [hereinafter CAP].

${ }^{16}$ Article 69, CAP. 
Consistent with international legal instruments to which Ethiopia is a party, international air carriage is seen here as the carriage of goods and passengers between places in different jurisdictions. ${ }^{17}$ Moreover, carriage between places within Ethiopia may be international if it involves an agreed stopping point outside Ethiopia. ${ }^{18}$

The Ethiopian law for international air carriage is mainly contained in the 1929 Warsaw Convention. The Convention, inter alia, contains rules on documents of carriage, the liability of the carrier, limitation of liability, and jurisdiction. The contents of some of these rules have been updated through series of protocols. ${ }^{19}$ Ethiopia, like many other states, is not a party to various

${ }^{17}$ Article 2(30), CAP; Article 1(2), the 1929 Convention for the Unification of Certain Rules relating to International Carriage by Air [hereinafter Warsaw Convention].

${ }^{18}$ Ibid.

${ }^{19}$ These protocols/conventions include the 1955 Hague Protocol (formally known as the Hague Protocol to Amend the Convention for the Unification of Certain Rules Relating to International Carriage by Air) [hereinafter Hague Protocol], the 1961 Guadalajara Convention (formally known as Convention, Supplementary to the Warsaw Convention, for the Unification of Certain Rules Relating to International Carriage by Air Performed by a Person Other than the Contracting Carrier, signed at Guadalajara on $18^{\text {th }}$ September 1961), the 1971 Guatemala Protocol (Protocol To Amend the Convention for the Unification of Certain Rules Relating to International Carriage by Air Signed At Warsaw On 12 October 1929 As Amended by the Protocol Done At The Hague on 28 September 1955 Signed At Guatemala City on 8 March 1971), and the four 1975 Montreal Additional Protocols (a.k.a Additional Protocol No.1 to Amend Convention for the Unification of Certain Rules Relating to International Carriage by Air Signed at Warsaw on 12 October 1929, Signed at Montreal, on 25 September 1975; Additional Protocol No. 2 to Amend the Convention for the Unification of Certain Rules Relating to International Carriage by Air Signed at Warsaw on 12 October 1929 as Amended by the Protocol Done at The Hague on 28 September 1955, Signed at Montreal on 25 September 1975; Additional Protocol No. 3 to Amend the Convention for the Unification of Certain Rules Relating to International Carriage by Air Signed at Warsaw on 12 October 1929 as Amended by the Protocol Done at The Hague on 28 September 1955 and at Guatemala City on 8 March 1971, Signed at Montreal on 25 September 1975; Montreal Protocol No. 4 to Amend the Convention for the Unification of Certain Rules Relating to International Carriage by Air Signed at Warsaw on 12 October 1929 as Amended by the Protocol Done at The Hague on 28 September 1955, Signed at Montreal on 25 September 1975)[hereinafter Montreal Protocol No. 1, Montreal Protocol No. 2, Montreal Protocol No. 3, Montreal Protocol No. 4, respectively]. Though they are not formal amendments to the 1929 Warsaw Convention, the IATA 1966 Montreal Agreement (formally known as Agreement Between Carriers of the "International Air Transport Association" (IATA) and the "Civil Aeronautics Board" (CAB) of the United States, Montreal 4/5/1966) 
amending protocols of the 1929 Warsaw Convention, and this limits unification and convergence in private international air law. ${ }^{20}$

This article overviews the Ethiopian law on international ${ }^{21}$ carriage by air. It does not as such deal with Ethiopian civil aviation law. It only focuses on the body of law governing the liability of the carrier in international air carriage. Section 1 highlights the historical evolution of the Warsaw system from an Ethiopian perspective. And, this is followed by a closer look at the substantive and procedural aspects of the Ethiopian law relating to international air carriage. Finally, a concluding remark along with suggestions for future actions is provided. It must be noted that the Commercial Code's rules on carriage by air, the Civil Aviation Proclamation's rules on civil aviation, and other Ethiopian transport legislations are not considered in this article. This is because these laws do not contain the Ethiopian law on international carriage by air.

\section{The Evolution of the Law on International Carriage by Air: An Ethiopian Perspective}

The 1929 Warsaw Convention which came into force in 1933 represents the first successful attempt to unify the law on international carriage by air. The Convention has, for example, succeeded in establishing the first universal system of documentation, carrier's liability, limitation of liability, period of limitation and jurisdiction. These in turn helped avoid some of the major conflicts and problems related to international air travel. ${ }^{22}$ Yet, dissatisfaction began to surface as time went by. For instance, leading aviation powers like the USA felt that the maximum limit of liability set in the Convention was

[hereinafter Montreal Agreement] and the 1995 Intercarrier Agreement (IATA Intercarrier Agreement on Passenger Liability of $31^{\text {st }}$ October 1995) are also important in influencing developments regarding the Warsaw rules on limitation of liability.

${ }^{20}$ See the signature, ratification and entry into force of the instruments listed in the preceding footnote from the ICAO webpage: $<\mathrm{http} / /$ www.icao.int/eshop/conventions_list.htm>

${ }^{21}$ Given however that the liability of any carrier is now governed by international instruments to which Ethiopia is a party, the article may as well be taken as an overview of the Ethiopian law on carriage by air in general.

${ }^{22}$ Philipson, supra note 7, $§ 1.2-1.6$; see also Cheng, B. (2004) "A New Era in the Law of International Carriage by Air: From Warsaw (1929) to Montreal (1999)," The International and Comparative Law Quarterly (53), p. 834 [hereinafter Cheng]. 
insufficient. ${ }^{23}$ Moreover, some provisions of the Convention were practically given inconsistent meanings in different jurisdictions. ${ }^{24}$

In 1955, attempts to improve the Warsaw Convention led to the adoption of the Hague Protocol. ${ }^{25}$ Among other things, the protocol addressed concerns regarding the limitation of carrier's liability and the concept of "wilful misconduct". It doubled the limit of liability contained in the Warsaw Convention $^{26}$ and replaced the controversial "wilful misconduct" with that of "intentional or reckless conduct" 27

The Warsaw-Hague Convention did not, however, attract the membership of some Warsaw states. For example, the USA refused to join the Hague Protocol as it was not still satisfied with the improved limitation cap. The USA maintained that advancements in technology and aviation insurance undermine the rationale behind according special protection to air carrier through limitation of liability. ${ }^{28}$ Interestingly, the USA even threatened to withdraw from the Warsaw system unless the limitation cap is significantly raised. ${ }^{29}$

${ }^{23}$ It must be noted that in the US and other western nations damages for personal injury were higher than the Warsaw Convention afforded; see, e.g., Cheng, supra note 22, pp. 835-836 and Philipson, supra note 7, § 1.11 -1.14.

${ }^{24}$ For an interesting review of judicial application of the supposedly uniform rules of Warsaw Convention, see Mankiewicz, R. (1972) "The Judicial Diversification of Uniform Private Law Conventions: The Warsaw Convention's Days in Court," The International and Comparative Law Quarterly (21), p. 718-757 [hereinafter Mankiewicz].

${ }^{25}$ For the full title of the Protocol, see note 19 supra.

${ }^{26}$ Under the Warsaw Convention as amended at The Hague, 1955, the limit of, for example, liability for personal injury is 250,000 gold francs - double the 125,000 gold francs limit under the unamended Warsaw Convention.

27 For further discussion on the concept of wilful misconduct and the problems associated with it, see notes 161-177 infra and the accompanying texts. Incidentally, other amendments include the simplification of rules regarding documents of carriage and extension of the protection accorded to the carrier to his servants and agents.

${ }^{28}$ Traditionally, limitation of liability afforded protection to carriers who invested in the then new and risky aviation business. This legal protection was necessary as both the aviation technology and insurance had not developed well. Nonetheless, technological advancements greatly reduced the risks of air transportation. It is now said the risks of air transport are by far lower than the risks in other modes of transport. Also, insurers have gradually begun to provide additional protection to various participants in the air carriage business. Despite this, developments in private international air law remained slower than the Americans and some other developed nations wanted. Particularly, the law remained favourable to carriers - presumably at the expense of passengers and cargo interests; see, e.g. Philipson, supra note $7, \S$ 1.11; Cheng, supra note 22, p. 836; Gesell, L. \& Dempsey (2005) Aviation and the Law. Chandler, Coast Aire Publications, p. 847 [hereinafter Gesell \& Dempsey]; 
As a response to the demands of USA that the liability limits be raised, a number of carriers from different countries came together to agree, with Civil Aeronautics Board of the United States, to a package of measures which would apply to all flights to, from or with an agreed stopping point in the USA. This accord is formally known as Agreement between Carriers of the International Air Transport Association (IATA) and the Civil Aeronautics Board (CAB) of the United States. ${ }^{30}$ Under the accord, the carrier is obliged to deliver to the passenger a ticket with a prescribed notice informing the passenger in clear terms that liability (to personal injury) in most cases is limited to $\$ 75,000.00$.

This agreement, which has a force of law in the USA, ${ }^{31}$ does not operate as an amendment of the Warsaw Convention. ${ }^{32}$ This is because the 1966 Montreal Agreement is not a treaty among state parties to the Warsaw Convention. It is rather a private agreement between members of IATA $^{33}$ and the Civil Aeronautics Board of the United States.

Another set of attempts to improve the Warsaw Convention include the 1961 Guadalajara Convention $^{34}$ and the 1971 Guatemala Protocol. ${ }^{35}$ While the Guadalajara Convention extends the Warsaw system to charter flights, which were arguably uncovered before, ${ }^{36}$ the Guatemala Protocol sought - albeit unsuccessfully - to revise the Warsaw-Hague rules on limitation of carrier's liability. ${ }^{37}$

Ethiopia is not a party to any of the amending conventions/protocols so far discussed. Yet, Ethiopian Airlines is a member of IATA and a party to the 1966 Montreal Agreement. The air ticket issued by Ethiopian Airlines thus states the following:

Lowenfeld, A. \& Mendelsohn, A. (1967) "The United States and the Warsaw Convention," Harvard Law Review (80), pp. 504 -516 [hereinafter Lowenfeld \& Mendelsohn].

${ }^{29}$ Cheng, supra note 22, p. 836; Philipson, supra note 7, § 1.18.

${ }^{30}$ It is also known as the 1966 Montreal Agreement.

${ }^{31}$ Philipson, supra note $7, \S 1.25$.

${ }^{32}$ Gesell \& Dempsey, supra note 28, pp. 849 -850; Diederiks-Verschoor, supra note 4, pp. 105-104.

33 IATA stands for the International Air Transport Association which is a private organisation of commercial airline companies.

${ }^{34}$ For the full title of the Convention, see note 19 supra.

${ }^{35}$ For the full title of the Protocol, see note 19 supra.

${ }^{36}$ See note 69 infra.

${ }^{37}$ To date, only few countries ratified the Protocol. Hence, it is not yet in force. (See the list of members from $<$ http://www.icao.int/icao/en/leb/Guatemala.pdf $>$ ). Even more, with the advent of the 1999 Montreal Convention, the Protocol is unlikely to attract new membership in the future. 
“...For such passengers on a journey to, from, or with an agreed stopping place in the United States of America... the liability of certain carrier parties to such special contracts, for death and personal injury to passengers is limited in most cases to proven damages not to exceed US $\$ 75,000.00$ per passenger." 38

The Warsaw Convention once again witnessed another improvement in 1975 when the four Montreal Additional Protocols were adopted. First, Second, and Third Protocols modernised the units of calculation used for computing the limits of liability under the 1929 Warsaw Convention, the 1955 Hague Protocol, and the 1971 Guatemala Protocol, respectively. The Special Drawing Rights $(\mathrm{SDR})^{39}$ is introduced in place of the Poincare or Convention franc used in previous instruments. Apart from introducing SDR in the calculation of damages involving cargo claims, the Fourth Protocol changed the liability rules relating to carriage of goods. Subject to some defences, the Protocol imposes a system of strict liability on a carrier. ${ }^{40}$ Ethiopia is signatory to the four Montreal Protocols, and all of them are in force since the last decade of the 20th century. ${ }^{41}$

Despite efforts over decades to improve the Warsaw system, compensation limits have still remained low for many developed countries. Interestingly, courts in some states started bypassing the limits set under the Warsaw Convention. ${ }^{42}$ In 1985, the Italian Constitutional Court declared the limitation of international air carriers' liability unconstitutional, eventually leading to the introduction (in Italy) of a new level of limit, i.e. 100,000 SDR. ${ }^{43}$ The move has affected air carriers flying to and from Italy. Ethiopian Airlines which runs

${ }^{38}$ See the Advice to International Passengers on Limitation of Liability section on passenger ticket issued by Ethiopian Airlines.

39 An SDR is a unit of account defined by the International Monetary Fund (IMF) which is converted into the appropriate national currency according to the rules of IMF and not by what the state determines. The rate on December $6^{\text {th }} 2011$, for example, shows that 1 SDR equals 26.88 Ethiopian Birr.

${ }^{40}$ See Articles IV-VI, Montreal Protocol No.4.

${ }^{41}$ See the list of ratifications by Ethiopia from the following link on the official website of ICAO:

$<$ http://www2.icao.int/en/leb/Status\%20of\%20individual\%20States/ethiopia_en.pdf $>$ Note however that Montreal Protocols No. 2 and 3 are of meagre significance as Ethiopia is not a party to the initial versions of the instruments which the Protocols try to update.

${ }^{42}$ In the US, where there has always been dissatisfaction with the Warsaw limitation of liability, the concept of wilful misconduct [discussed in detail below] has sometimes been interpreted broad enough to break the limit on carrier's liability; see, e.g., Milde, M. (1996) "Warsaw Requiem or Unfinished symphony?" Lloyd's Aviation Quarterly (Part One), p. 37-51.

${ }^{43}$ Diederiks-Verschoor, supra note 4, p. 110. 
scheduled flights to and from the Italian capital Rome, for example, maintains a separate liability undertaking regarding claims brought before Italian courts. ${ }^{44}$

A similar effort to raise the limits of liability was initiated by Japanese airlines in early 1990s. Japanese airlines did not only opted to raise the limit of liability but also showed willingness to waive the defences under Article 20 (1), Warsaw Convention, so long as the claims involved do not exceed 100,000 SDR. ${ }^{45}$ Meanwhile, IATA sponsored the 1995 Intercarrier Agreement on Passenger Liability. An important aspect of the 1995 Intercarrier Agreement is that the limitation of liability and recoverable damages in Article 22(1) of the Warsaw Convention as to claims for death, wounding or other bodily injury of a passenger is waived and determined by reference to the law of the domicile of the passenger. ${ }^{46}$

In 1997, the European Union passed a regulation that applies to all European carriers, including airlines operating charter flights. This regulation - EC Regulation No. 2027/97 - imposes unlimited liability on carriers and requires them not to invoke defences for an amount up to $100,000 \mathrm{SDR} .{ }^{47}$ It is, however, to be noted that non-European carriers that serve EU destinations (including Ethiopian Airlines) would not be affected by the regulation. ${ }^{48}$

Further attempts to improve and consolidate the highly fragmented private international air law resulted in the 1999 Montreal Convention. ${ }^{49}$ The Convention's liability regime is comparable with the 1995 IATA Intercarrier Agreement and the EC Regulation No. 2027/97 in that it provides for absolute

${ }^{44}$ Within the ticket Ethiopian Airlines issues, one finds a notice stating that "for all international carriage to which the Warsaw Convention applies...in any action brought before an Italian court, the limit of liability shall be 100,000 SDRs..."

${ }^{45}$ Cheng, supra note 22, p.842; Diederiks-Verschoor, supra note 4, p. 111; Philipson, supra note 7, § 1-40.

${ }^{46}$ Consequently, passengers domiciling in countries where compensations for personal injury actions are higher than the Warsaw limits would benefit. Incidentally, air carriers which are members to this agreement were taken to have withdrawn from the comparable Montreal Agreement of 1966 (Philipson, supra note 7, § 1-43). Ethiopian Airlines is not a party to 1995 Intercarrier Agreement and hence remains committed to the 1966 Montreal Agreement.

${ }^{47}$ See 92 of Annex, EC Regulation 2027/97, "on air carrier liability in respect of the carriage of passengers and their baggage by air" Official Journal of the European Union.

48 Diederiks-Verschoor, supra note 4, p. 112; nonetheless, some provisions of the Regulation proved inconsistent with "the treaty obligations owed by EU states to non-EU states under the Warsaw Convention;" see, e.g., Philipson, supra note 7, § 146.

49 Convention for the Unification of Certain Rules for International Carriage by Air, Montreal, 28 May 1999 [hereinafter Montreal Convention]. 
carrier liability up to 100,000 SDRs. ${ }^{50}$ Moreover, it obliges carriers to maintain adequate insurance to cover their liability. ${ }^{51}$ It also introduces a "fifth jurisdiction",52 for personal injury or death actions. The Montreal Convention came into force in 2003 and enjoys membership of some 100 states as of December 2011..$^{53}$ The Convention is expected to gradually replace the whole Warsaw system (as amended by different protocols). Ethiopia is not a party to this new international instrument on carriage by air.

In sum, the Warsaw Convention along with the 1975 Montreal Additional Protocols forms the Ethiopian law on international air carriage. Neither domestic law (e.g. the Commercial Code or the Civil Aviation Proclamation) nor international instruments ${ }^{54}$ other than the Warsaw Convention as amended by the 1975 Montreal Protocols governs the liability of an international air carrier. Other laws would apply only when the Warsaw Convention (as amended by the Montreal Protocols) does not apply. Moreover, contractual stipulations ${ }^{55}$ may govern the liability of the carrier. Nonetheless, such contractual stipulations are, as would be seen later, ${ }^{56}$ subject to the mandatory provisions of the Warsaw Convention.

\section{The Coverage of the Warsaw Convention}

\section{1- Scope of Application of the Warsaw Convention}

The Warsaw Convention applies to "international carriage" ${ }^{57}$ International carriage, for the purpose of Warsaw Convention, represents carriage whose place of departure and place of destination are situated within the territories of two High Contracting States. ${ }^{58}$ Flights within the territory of a single

${ }^{50}$ See Articles 17 and 21 of Montreal Convention.

${ }^{51}$ Article 50, Montreal Convention.

${ }^{52}$ Ibid, Article 33(2); See note 85 infra and the accompanying texts.

${ }^{53} \mathrm{See}$ list of ratifications from $<\mathrm{http}: / / \mathrm{www}$.icao.int/icao/en/leb/mtl99.pdf>.

${ }_{55}^{54}$ But see notes 96 et seq., infra and the accompanying texts.

${ }^{55}$ Ethiopian Airlines - the sole Ethiopian participant in international air business - is committed to the 1966 Montreal Agreement that in most cases guarantee passengers carried to and from the United States proven damages of $\$ 75,000.00$ for death and personal injury. The same carrier undertakes that the limit of liability be $100,000.00$ SDRs should actions (involving international carriage to which the Warsaw Convention applies) be brought before an Italian Court. Such contractual stipulations bind the carrier; hence, contractual terms may also govern the liability of the carrier in carriage by air.

${ }^{56}$ See, e.g., note 78 infra and the accompanying text.

${ }^{57}$ Article 1(2), Warsaw Convention.

${ }^{58}$ Ibid. 
Contracting State would also be international if they involve an agreed stopping place outside the territory of the concerned Contracting State. ${ }^{59}$ The Convention does not thus apply to "non-international carriage". Nonetheless, some countries extend the application of the Warsaw regime to domestic carriage. ${ }^{60}$

The Warsaw Convention "does not apply to experimental air carriage undertaken with a view to establish a regular line of air navigation." ${ }^{, 61}$ It does not also apply to carriage "undertaken in extraordinary circumstances outside the normal scope of an air carrier's business." ${ }^{22}$ Yet, it applies to carriage directly performed by the State ${ }^{63}$ unless a reservation excluding this type of international carriage from the scope of applicability of the Convention is made. ${ }^{64}$ Ethiopia has made a reservation with regard to Article 2(1) of the Convention. ${ }^{65}$ Accordingly, the Convention shall not apply to international air transport carried out directly by the State or legally constituted public bodies.

Definitions given to "aircraft", "passenger" and "carrier" may also determine the scope of application of the Convention. It is argued that carriage by, for example, hovercraft ${ }^{66}$ is excluded from the ambit of the Convention. ${ }^{67}$ Similarly, an airline employee cannot claim compensation under the Warsaw Convention as she is not "passenger" 68 for the purpose of the Convention. In numerous civilian jurisdictions, the Warsaw Convention does not govern the liability of the actual carrier in charterparty or interchange situations. The scope of application of the Convention, in these jurisdictions, is thus limited to cases

${ }^{59}$ Ibid.

${ }^{60}$ Diederiks-Verschoor, supra note 4, p. 60; Ethiopia is also one of those countries that extend the application of the Convention to non-international flights (see note 16 supra.).

${ }^{61}$ Article 34, Warsaw Convention.

${ }^{62}$ Ibid.

${ }^{63}$ Ibid, Article 2.

${ }^{64}$ See the Additional Protocol to the Warsaw Convention, Done at Warsaw on the $12^{\text {th }}$ October, 1929.

${ }^{65}$ See $<$ http://www2.icao.int/en/leb/Status\%20of\%20individual\%20States/ethiopia_en.pdf $>$

${ }^{66}$ Hovercraft is a type of vehicle that travels in the air using a strong current of air forced out beneath it.

${ }^{67}$ Diederiks-Verschoor, supra note 4, p. 63.

68 The Warsaw Convention presupposes the contractual relationship of air passengers/shippers and the air carrier. It does not for example govern damage sustained by third parties on ground as a result of air crash. This is because such parties are not related to the air carrier through contract of air carriage; see also Diederiks-Verschoor, Ibid. 
where the carrier is a party to the carriage contract, i.e., a contracting carrier. ${ }^{69}$ In contrast, Anglo-American jurisdictions maintain that "carrier", for the purpose of Articles 17-19 of the Convention, refers to "actual carrier"

Subject to the limitations on the scope of application discussed above, Ethiopian courts must always apply the Warsaw Convention should countries connected by an international carriage belong to the Warsaw Convention. ${ }^{71}$ Article 24 excludes the application of other national and international laws in claims involving the liability of the carrier. ${ }^{72}$ However, Ethiopian courts have

${ }^{69}$ This appears to be the case in Ethiopia as well; see Negist Mekonnen et al $v$ Ethiopian Airlines, Inc et al., note 14 supra.

${ }^{70}$ In a contract of carriage, actual carrier is the one who actually undertakes the carriage though it is not the carrier who has contracted with the passenger or shipper. In some jurisdictions, contracting carrier and actual carrier are treated differently. For an excellent appraisal of the disagreement between civilian and common lawyers as to the exact definition of carrier under Articles 17-19 of Warsaw Convention, see Mankiewicz, R. (1961) "Charter and Interchange of Aircraft and the Warsaw Convention: A Study of Problems Arising from the National Application of Conventions for the Unification of Private Law" International and Comparative Law Quarterly (10), pp. 707-725; See also Philipson, supra note 7, § 1-15. Incidentally, note that the ambiguity with the exact scope of the Warsaw Convention vis-à-vis air charterparty is one of the reasons for the introduction of the 1961 Guadalajara Convention which, as discussed earlier, expressly addresses the issue of the liability of the actual carrier.

${ }^{71}$ Incidentally, Ethiopian courts may decline to apply the Warsaw Convention if one of the countries connected by the international air carriage does not belong to the convention. As a matter of public international law, states are not obliged to give effect to Warsaw Convention unless the later forms a common treaty in force between the states of places connected in international carriage. For the application of this principle, see the Chubb and Son v Asiana Airlines 214 F. 3d 301 (2 ${ }^{\text {nd }}$ Cir. 2000) where the U.S. Court of Appeals for the Second Circuit, applying rules of international treaty interpretation, held that US courts could not assume jurisdiction as there was no common treaty in force between the US and South Korea [the case involved a South Korean air carrier who was sued for lost cargos]. At the time, USA was a party to the Warsaw Convention while South Korea was a party to the Hague Protocol, but did not separately adhere to the original Warsaw Convention.

Finally, note that the wider applicability (in Ethiopia) of this principle of public international law is weighed down by Article 69 of the Civil Aviation Proclamation which anyway requires the application of international legal instruments in determining the liability of any carrier.

${ }^{72}$ Note however that Article 24 does not exclude the application of domestic laws to, for example, questions as to who are the persons who have the right to bring suit under Article 17 and what are their respective rights (see Article 24(2), Warsaw Convention). Also, negotiability of airway bills is determined by domestic law, rather 
had a poor track record of enforcing international instruments including the Warsaw Convention. In one case ${ }^{73}$ involving damage to cargo carried from Rome (Italy) to Addis Ababa, the High Court of Addis Ababa and, on appeal, the Ethiopian Supreme Court applied the Commercial Code instead of the Warsaw Convention. The courts did this without being justified by any of the limitations discussed above. ${ }^{74}$ Such practice goes against the very purpose of the Warsaw Convention, particularly Article $24 .^{75}$ The inaccessibility of the Warsaw Convention in the working language of Ethiopian courts limits the practical applicability of the Convention. Ethiopia should thus publish international instruments it ratifies in local languages so as to facilitate its application in real cases. Nonetheless, the non-publication of the Convention in Amharic (or any other local language) does not seem to justify failure to apply international instruments ratified by Ethiopia which constitute "integral parts of the law of the land" by virtue of Article 9(4) of the 1995 Constitution of the Federal Democratic Republic of Ethiopia.

\section{2- Jurisdiction}

The Federal High Court assumes material jurisdiction over issues of international air carriage. ${ }^{76}$ This court must not however determine matters of judicial jurisdiction based on the unwritten and arguably unknown Ethiopian

than Warsaw Convention. In sum, the exclusivity of the Warsaw Convention is limited to matters pertaining to the liability of the carrier.

${ }^{73}$ Mengistu G. v Ethiopian Airlines and Customs \& Excise Tax Administration, Supreme Court of Ethiopia, Civil Appeal File No. 825/81 [reported in Yohannes H. $\&$ et al. (eds.), Selected Judgements. Addis Ababa, Commercial Printing Press, Vol. 1, pp. 37-45].

${ }^{74}$ The facts of the case reveal that the goods damaged are carried from Rome, Italy to Addis Ababa, Ethiopia by a commercial carrier in an ordinary circumstance. Also, Ethiopia and Italy were in a Warsaw Convention relationship by the time the carriage was undertaken. Hence, Warsaw Convention should have applied.

75 The Warsaw Convention aims at brining uniformity to the law relating to international air carrier's liability. In so doing, it requires the exclusive applicability of Convention rules in actions for damages based on Articles 17-19. Moreover, the jurisprudence in some jurisdictions is that carriers may not be sued under municipal law where the suit is based on accidents and occurrences covered under Articles 1718. Interestingly, it is also held that carriers are not subject to municipal laws where they are not liable under the Convention. See Philipson, supra note 7, § 7-9-7.19.

${ }^{76}$ International air carriage is a matter of private international law. Of course, a narrow definition of private international law associates it to what otherwise is known as conflict of laws. If we agree on a broader definition of private international law, cases regarding international air carriage belong to the first instance civil jurisdiction of the Federal High Court; see Article 11(2) (a) of Federal Courts Proclamation, 1996, Federal Negarit Gazeta, Proclamation No. 25, Year 2, No. 13. 
law of private international law. Judicial jurisdiction in matters that involve international air carriage is determined according to Article 28 of the Warsaw Convention. The rules on jurisdiction are exclusive. ${ }^{77}$ Parties may not contract out Article 28. ${ }^{78}$ But, there are authorities according to which parties may, after the occurrence of the damage, contract on a more appropriate jurisdiction. ${ }^{79}$

The Warsaw Convention establishes "the four jurisdiction fora". A plaintiff may bring her actions for damage in one of the following forums which in anyway has to be a court of one of the Contracting Parties:

a) The court of the place where the carrier is ordinarily resident;

b) The court of the place where the carrier has his principal place of business;

c) The court of the place where the carrier has an establishment by which the contract has been made; or

d) The court of the place of destination.

Often, the court of the place where the carrier is ordinarily resident is the same as the court of principal place of business. ${ }^{80}$ Jurisprudence from some Warsaw nations reveals that plaintiffs relying on these grounds of jurisdictions need to show that the carrier maintains headquarters - where the main part of the executive and management work of the business is conducted. ${ }^{81}$

The ever increasing involvement of travel and shipping agents in intermediating contracts of carriage evoke questions as to whether the court of the place where such intermediaries reside can assume jurisdiction. In other words, should one take travel agents as establishments for the purpose of Article 28 ? The answer seems in the negative as courts in some jurisdictions are not yet prepared to accord agencies the status of establishment. In particular, French courts appear to assume jurisdiction based on the third ground only when the carrier has its own establishment, e.g. a directly owned ticket office. ${ }^{82}$

The court of the place of destination may assume jurisdiction. For this purpose, courts often take as the place of destination the one indicated as such in the ticket. ${ }^{83}$

\footnotetext{
${ }^{77}$ Article 32, Warsaw Convention.

${ }^{78}$ Ibid.

${ }^{79}$ Philipson, supra note 7, § 11-37; Diederiks-Verschoor, supra note 4, p. 93.

${ }^{80}$ Philipson, supra note $4, \S 11-27$.

${ }^{81}$ See, e.g., Winsor v United Airlines, US District Court, Eastern District of New York (25 June 1957) cited in Diederiks-Verschoor, supra note 4, p. 92.

${ }^{82}$ See, e.g., cases cited and discussed in Philipson, supra note 7, § 11-31 and DiederiksVerschoor, supra note 4, pp. 92-93.

${ }^{83}$ Philipson, supra note $7, \S 11-33$.
} 
Finally, the non-inclusion of the places where (1) the damage has occurred, (2) the offense or tort occurred, and (3) the victim resides as the basis of judicial jurisdiction dissatisfied some Warsaw members, mainly the USA. ${ }^{84}$ The 1999 Montreal Convention partially, if not completely, has improved the rules by recognising a fifth jurisdiction based on the domicile of the victim. ${ }^{85}$ As Ethiopia is not a party to the Montreal Convention, its courts cannot assume jurisdiction based on the domicile of the victim.

\section{Documents in International Carriage by Air}

Chapter Two of the Warsaw Convention prescribes rules regarding documents of carriage. The documents are passenger ticket, luggage ticket (baggage check) and air consignment note (air waybill). The Convention requires, under the pain of penalty, the carrier to deliver documents of carriage containing specific details.

If the carrier accepts a passenger without a passenger ticket having been delivered it is not entitled to avail himself of the defences and limits to his liability. ${ }^{86}$ Practically, carriers have also been exposed to unlimited liability where defective tickets (e.g. where the issued ticket fails to provide the passenger adequate notice on the conditions of contract) were issued. ${ }^{87}$ This rule, which was meant to protect the interest of the passenger, ${ }^{88}$ has been challenged in the advent of ticketless travel. ${ }^{89}$ Experience has shown that the rule is rather detrimental to passengers because carriers who spend big money to

${ }^{84}$ On this point see, e.g., Luongo, N. (2009) "The Fifth Jurisdiction: The American Dream" Annals of Air and Space Law, (34), 437 et seq.; Lownefeld \& Mandelsohn, supra note 28 , pp. 522-526.

${ }^{85}$ Article 33(2), Montreal Convention allows actions to be brought before the court of the State Party in which at the time of the accident the passenger has his domicile.

${ }^{86}$ Article 3(2), Warsaw Convention.

87 This is however incompatible with the literal texts of the original Warsaw Convention which sanctions only the failure of the carrier to issue tickets; it does not as such sanction the delivery of tickets which, for example, does not provide adequate liability notice. The rule "defective ticket is no ticket" has however been incorporated in Article 3 of the 1955 Hague Protocol which provides "the carrier shall not be entitled to avail himself of the provisions which limit his liability if the ticket issued does not include the notice required by the Warsaw-Hague Convention". Note however that Ethiopia is not a party to the 1955 Hague Protocol and hence the rule "defective ticket is no ticket" is not applicable. But see Article 607(2), Commercial Code which contains a provision comparable with Article 3(2), Hague Protocol.

${ }^{88}$ The rule is predicated on the theory that passengers are aware of the limitation on the carrier's liability only if ticket is delivered to them prior to boarding; see. e.g., Philipson, supra note 7, § 5-13.

${ }^{89}$ Diederiks-Verschoor, supra note 4, p. 66; Philipson, supra note 7, § 5-11. 
comply with the documentation requirements shift the cost to consumers. ${ }^{90}$ Besides, simpler procedures of booking (e.g. telephone booking and online booking) - which do not necessarily meet the terms of Article 3 and other provisions of the Convention - may in fact benefit passengers. ${ }^{91}$

Apart from passenger ticket, luggage ticket (baggage check) containing the particulars listed under Article 3(4) must be issued by the carrier. The carrier cannot carry baggage without issuing a luggage ticket. In the absence of this ticket, the carrier cannot avail itself of the provisions of the Convention which exclude or limit liability. Similarly, a carrier cannot exclude or limit liability should it issue a baggage check that does not contain the particulars set out at Articles 3(4)(d), (f) and (h). ${ }^{92}$

As a matter of practice, airlines do not issue a separate luggage ticket. Instead, a passenger ticket combining a baggage check or a baggage check that does not contain the mandatorily required particulars is what commercial airlines, including Ethiopian, issue to passengers. ${ }^{93}$ Such practices may expose carriers to penalties. ${ }^{94}$

With regard to the rules regarding air waybill ${ }^{95}$ (a document acknowledging the receipt of goods by the carrier), the original rules are contained in Articles 5-

${ }^{90}$ Diederiks-Verschoor, supra note 4, p. 66.

${ }^{91}$ For an excellent review of the benefits and limitations of simpler procedure of ticketing such as electronic tickets, see, e.g., Rueda, A. (2002) "The Warsaw Convention and Electronic Ticketing," Journal of Air Law and Commerce, (67), pp. 401-464.

${ }^{92}$ Article 4(3), Warsaw Convention.

${ }^{93}$ See, e.g., Diederiks-Verschoor, supra note 4, p. 67-68; Note that documents issued by Ethiopian Airlines are named "Passenger Ticket and Baggage Check."

${ }^{94}$ See, e.g., Philipson, supra note 7, § 5-60 - 5-62 and Diederiks-Verschoor, supra note 4, p. 74. Incidentally, the 1955 Hague Protocol -which significantly reduced the requirements regarding form and content of passenger and luggage tickets, authorises the incorporation of baggage check in the passenger ticket. Also, the Montreal Convention - another international instrument to which Ethiopia has not subscribed for - has done away with the rules sanctioning non-compliance with baggage check requirements. Instead, it relies on the principle of absolute liability of the carrier in protecting air passengers; see, e.g., Cheng, supra note 22, p. 848.

95 Once the goods have been accepted for shipment by the carrier, an air waybill covering the goods will be issued. The air waybill is made in three "original" copies each for the carrier, the consignor and the consignee (Art.6 (1)-(2), Warsaw Convention). The bill, especially the one accompanying the goods (the one marked "for the consignee"), must be signed by the carrier and the consigner himself (see Art.6 (2), Warsaw Convention). Such air consignment note is important in contract of carriage of goods by air for it performs different functions. Most importantly, it supports the underlying contract of carriage between the carrier and the consignor; 
16 of the Warsaw Convention. These rules have been amended by The Hague and Montreal Protocol No.4. Although Ethiopia was not initially a party to the Hague Protocol, membership in the Montreal Protocol No.4 renders Ethiopia a party to the "Warsaw Convention as amended by the Hague (1955) and Protocol No. 4 of Montreal (1975) Protocols. ${ }^{96}$ Thus, the Ethiopian law on international carriage of goods by air is to be found within the provisions of the WarsawHague-Montreal system.

The function of air waybill in carriage by air is comparable with the function of bills of lading in carriage of goods by sea. Just like maritime bills of lading, air waybills do have a receipt function. As such, they are prima facie evidence of the receipt of goods. ${ }^{97}$ Furthermore, air waybills are prima facie evidence of the conditions of carriage and the conclusion of contract for carriage of the cargo that they cover. ${ }^{98}$

Air waybill must contain the particulars enumerated under Article 8. If the carrier accepts cargo without a bill being made out or if a bill does not contain all the particulars set out in Article 8 (a) to (i) inclusive and (q), it cannot avail itself of the exclusion or limitation of liability under the Convention. ${ }^{99}$ Omissions or errors in the waybill concerning particulars set out in Article 8 (j)$(\mathrm{p})^{100}$ are not, however, sanctioned. Furthermore, the jurisprudence in some

and governs the relationship between the carrier and the consignee who may not necessarily be a principal party to the contract of carriage (see Art.11, Warsaw Convention).

96 Article XV, Montreal Protocol No. 4; note however that Ethiopia is not bound by every provisions of the Hague Protocol. Article XV, Montreal Protocol No. 4, only brings about Ethiopia's membership to the Hague rules regarding carriage of goods but not luggage and passengers.

${ }^{97}$ See Article 11(1), Warsaw Convention cum Article 186, the Maritime Code of the Empire of Ethiopia, 1960, Negarit Gazeta, Proclamation No.164/1960, $19^{\text {th }}$ Year, No.1 [hereinafter the Maritime Code].

${ }^{98}$ Article 11(1), Warsaw Convention cum Articles 183 and 186, Maritime Code. Apart from the evidentiary functions, air waybills serve as a control document by which constructive possession is transferred. The bill, especially the one marked "for the consignee," facilitates the relationship between the carrier and the consignee. Put in other words, an air waybill constitutes an acknowledgement by the carrier that the goods will be delivered to the holder of the bill; see generally Articles 11-13, Warsaw Convention.

${ }^{99}$ Ibid, Article 9.

${ }^{100}$ These particulars relate to the apparent condition of the goods and of the packing, the freight and its mode of payment, the price of the goods, the amount of the value declared in accordance with Article 22(2), the number of parts of the waybill, the documents handed to the carrier to accompany the air consignment note, the route and time fixed for the carriage. 
states imply omission of particulars set out in Article 8 (a) - (i) inclusive and (q) will be sanctioned if the omission or the error was of "commercial significance" or "prejudicial to the consignee". 101

The "no prejudice" test has influenced the Hague Protocol which has changed the Warsaw Convention's requirement that the waybill contain numerous particulars. Under the Hague Protocol, the waybill need only contain such particulars as places of departure and destination, a stopping place, if any, and a notice of liability limitation. ${ }^{102}$ Omissions of particulars regarding departing, stopping and arrival places are not therefore sanctioned anymore. However, the carrier forfeits the privilege of limiting its liability under Article 22 of the Warsaw Convention if the waybill does not contain a notice of liability limitation. ${ }^{103}$

The Warsaw-Hague rules on air waybill have further been improved by the 1975 Montreal Protocol No 4. With the consent of the consignor, the carrier is now allowed to deliver any substitute such as electronic airway bills ${ }^{104}$ (in lieu of ordinary waybills) which would preserve a record of the carriage to be performed. The carrier indeed benefits from the privilege of limitation of liability notwithstanding failure to comply with the notice requirement under Article 8 of the Warsaw-Hague system. ${ }^{105}$ In other words, the Ethiopian law on air waybills have now been simplified in that it does not anymore sanction failure to comply with the notice requirement. In contrast, the law on passenger ticket and baggage check remains unchanged and hence it still sanctions failure to comply with the requirements of form and content under Article 3 of the Warsaw Convention.

As noted earlier, air waybill constitutes prima facie evidence of the condition of the goods carried. Cargo is often concealed in packaging and, in effect, carriers will have little opportunity (in the course of loading) to independently verify the statements of consignors regarding the nature, condition, and quantity of their cargos. The consignor is thus liable to the carrier for any damage that might result from the absence or insufficiency of the indications and the statements he inserts in the air waybill. ${ }^{106}$ Incidentally, courts in various jurisdictions have held that the airway bill only serves as prima facie evidence

${ }^{101}$ Such an approach, which is not of course in line with the literal interpretation of Article 9 of the Warsaw Convention, has been pervasive in the USA; see, e.g., Philipson, supra note 7, §6.17-6.18; Diederiks-Verschoor, supra note 4, p. 69.

${ }^{102}$ Article III, Hague Protocol.

${ }^{103}$ Ibid.

${ }^{104}$ See Article III, Montreal Protocol No. 4.

${ }^{105}$ Article III, Montreal Protocol No. 4 deletes Warsaw-Hague rules that used to sanction the omission of particulars entered into air waybills.

${ }^{106}$ Ibid. 
of the external condition of the packaging and have regarded the internal condition as latent. ${ }^{107}$ Finally, it should be noted that air waybills are negotiable ${ }^{108}$ thereby facilitating documentary sale and the combined air-sea or air-land transportation of goods. ${ }^{109}$

\section{Liability of the International Air Carrier}

\section{1- Sources of Liability of the International Air Carrier}

The rules on carriers' liability are embodied in Articles 17-19 of the Warsaw Convention. Article 17 stipulates the carrier's liability for injury and death of passengers, and Article 18 states the rules on carriers' liability for loss or damage to "registered luggage or any goods". Article 19 provides that the carrier is liable for damage caused by delay. These rules are predicated on the principle of fault, although the burden of proof is assumed by the carrier himself (hence "a reversed burden of proof") ${ }^{110}$ in return for the privilege of limiting liability to the amount set out in Article 22.

Under Article 17, the carrier is liable for the "death and wounding of a passenger or any other bodily injury suffered by a passenger if the accident which caused the damage took place on board the aircraft or in the course of any of the operations of embarking or disembarking". As "accident", "bodily injury" and "embarking/disembarking" are not defined anywhere in the Convention, uniform interpretation of Article 17 is difficult. Though there appears to be consensus in considering "accident" as "unexpected or unusual event other than the normal operation of the aircraft which is external to the passenger," 111 there have been instances where comparable facts led to different decisions in various jurisdictions. ${ }^{112}$ Meanwhile, the phrase "bodily injury," which appears to merely

${ }^{107}$ Diederiks-Verschoor, supra note 4, p. 70.

108 There used to be uncertainty regarding the negotiability of air waybills (see, e.g., Diederiks-Verschoor, supra note 4, p. 69 , and Philipson, supra note $7, \S 6.2$ ). It is now widely held that the Warsaw Convention does not prohibit the issuance of negotiable air waybills. See also Articles 616 of the Commercial Code which expressly allows negotiable airway bills.

${ }^{109}$ Diederiks-Verschoor, supra note 4, p. 69.

${ }^{110}$ Ibid, p. 72.

${ }^{111}$ Air France v Saks, 470 U.S. 392, 105 S. Ct. 1338 (1985); see also Philipson, supra note 7, $§ 7.32$ - 7.43 and Cobbs, P. (1999) "The Shifting Meaning of "Accident" under Article 17 of the Warsaw Convention: What did the Airline know and what did it do about it?" Air and Space Law (24), pp. 123 et seq. for the jurisprudence of other jurisdictions on "accident."

112 The issue whether "inaction" constitutes "accident" has been divisive; see, e.g., Gesell \& Dempsey, supra note 28, pp. 869-873; International Air Transport 
refer to physical injury, is constructed to include mental (emotional) injury unaccompanied by physical injury. ${ }^{113}$ Moreover, the word "embarking" or "disembarking" which defines the duration of the accident has been interpreted differently in different jurisdictions. ${ }^{114}$

Association (2007) The Liability Reporter. New York, Condon \& Forsyth LLP, pp. 33-35 and the foreword as well.

${ }^{113}$ See, e.g., a 1985 Israeli case Compagnie Air France c. Consorts Teichner [reported in RFDA or Revue Française de Droit Aérien, (39), pp. 232 et seq.] where the Israeli Supreme Court awarded compensation for emotional injury. But see Eastern Airlines $v$ Floyd, 499 US 530 (1991) which in the USA settled the matter in favor of the carrier. As the matter was so controversial before the US Supreme Court's holding that passengers may not recover mental anguish unaccompanied by physical injury, the literature on "bodily injury" (Article 17) is relatively rich; see, e.g., Collins, L. (1994) "Pre- and Post-Impact Pain and Suffering and Mental Anguish in Aviation Accidents" Journal of Air Law \& Commerce, (59), pp. 402 et seq.; Holmes, S. (1993) "Recovery for Purely Mental Injuries Under the Warsaw Convention" Journal of Air Law \& Commerce, (58), pp. 1205 et seq.; Eaton, D. (1993) "Recovery for Purely Emotional Distress Under the Warsaw Convention: Narrow Construction of Lesion Corporelle in Eastern Airlines, Inc. v. Floyd" Wisconsin Law Review, (1993), pp. 563 et seq.[hereinafter Eaton]; Sisk, G. (1990) "Recovery for Emotional Distress Under the Warsaw Convention: the Elusive Search for the French Legal Meaning of Lesion Corporelle" Texas International Law Journal, (25), pp. 127 et seq.

114 Determining whether an accident took place during "embarking" or "disembarking" is not as easy as establishing the occurrence of accident "on board aircraft". Different tests or approaches (to establish accidents occurring in the process of embarking or disembarking) have been developed in different jurisdictions. Among the civil law members of the Warsaw Convention, "the zone of aviation risk" and "the control" tests apply in determining the process of embarking and disembarking. The zone of aviation risk test limits the application of Article 17 to only accidents occurring inside airport terminals where the aviation risk is greater. On the other hand, the control test allow courts to exclude accidents, though occurring in the aviation risk zone, that cannot reasonably be attributable to the fault of the carrier as in, for example, cases where a passenger sustained injury while using the escalator in the airport entrance hall. In common law jurisdictions, notably the US, a "tripartite test" is employed in determining the process of embarking or disembarking for the purpose of Article 17. The test, predicated on the ruling of US courts in Day [Day v Trans World Airlines 528 F 2d 31 ( $2^{\text {nd }}$ Circuit, 1976)] and Evangelinos [550 F 2d 152 ( $3^{\text {rd }}$ Circuit, 1976)] cases, emphasises the importance of (1) the location of the accident, (2) the nature of the passenger's activity during the accident and (3) the carrier's control over the injured passenger at the time of the accident. The two tests are not however mutually exclusive. Notwithstanding the type of tests employed, one would likely reach at similar conclusions except in 
To the best knowledge of the author, Ethiopian courts have not ruled on these aspects of Article 17 of the Warsaw Convention. As Ethiopian courts are now expected to widely ${ }^{115}$ apply the Warsaw Convention, the relatively rich jurisprudence in other Warsaw jurisdictions can inform judicial interpretation in Ethiopian courts when cases require the understanding and interpretation of Article 17. It is thus submitted that courts need to apply definitions and tests of "accident", "bodily injury" and "embarking/disembarking" in light of the jurisprudence and doctrinal interpretation that have developed elsewhere. ${ }^{116} \mathrm{In}$ particular, courts must at least (1) distinguish "accident" from "occurrence," (2) refrain from widely interpreting "bodily injury"; ${ }^{118}$ and (3) limit the scope of the process of "embarking/disembarking" to activities undertaken in the "zone of aviation risk". 119

A final remark on the jurisprudence of Article 17 involves the Montreal Agreement of 1966 which commits IATA members including Ethiopian Airlines to issue tickets that embody the statement which expressly indicates the limitation of liability under the conditions stated earlier in Section 1 , note $38 .^{120}$ This statement of liability includes personal injury and it is argued ${ }^{121}$ that "personal injury" is not synonymous with the notions of "wounding... and bodily injury" as envisaged under Article 17 of the Warsaw Convention. Accordingly, "personal injury" is believed to entitle compensation for mental

marginal cases; see Diederiks-Verschoor, supra note 4, p. 79-80 and Philipson, supra note $7, \S 7.44-7.59$.

${ }_{116}^{115}$ See n. 13-15 supra and the accompanying texts.

${ }^{116}$ In this regard, the jurisprudence from the USA, UK and France - where the Warsaw Convention rules have been litigated since the first half of the $20^{\text {th }}$ century - would be instructive.

117 "Occurrence" is used under Article 18(1) within the context of carrier's liability for damage to goods and luggage. And, it has rightly been distinguished from "accident" under Article 17; see, e.g., Philipson, supra note 7, § 7.32.

${ }^{118}$ This would enable courts not to depart from the literal meanings of the authentic text of the Convention as well as the intent of the drafters of the Convention; see note 110 supra and Philipson, supra note $7, \S 7.25-7.28$.

${ }^{119}$ Even then, the issue of control also must be taken into account so as to avoid holding the carrier liable to damages caused by accidents occurring inside the zone of aviation risk but without the carrier being in charge of the passenger; see note 114 supra.

${ }^{120}$ Advice to International Passengers on Limitation of Liability, note 38 supra.

121 See, e.g., Krytsal v British Overseas Airways Corp., US District Court, Central District of California (10 September 1975) cited in Diederiks-Verschoor, supra note 4, p. 106 and Eaton, p. 577; Note however that the tendency to exclude compensation to purely mental injury pervades even after the most passengerfriendly Montreal Convention of 1999 (See Philipson, supra note 7, § 7.31). 
injury even where it is not accompanied by physical injury. ${ }^{122}$ In employing the term "personal injury" (instead of "wounding and bodily injury") in its passenger ticket, Ethiopian Airlines is thus arguably ready to redress passengers for mental injury unaccompanied by physical injury. In the absence of any local jurisprudence on this point, it is unclear whether Ethiopian courts maintain a distinction between "bodily injury" (Article 17, Warsaw Convention) and "personal injury" (Advice to International Passengers on Limitation of Liability, Passenger Ticket and Baggage Check, Issued by Ethiopian Airlines).

Under Article 18, the international carrier is presumed liable for "destruction, loss or damage to registered ${ }^{123}$ luggage or any goods ${ }^{124}$ if the occurrence which caused the damage took place during the carriage by air." Occurrence has been defined more broadly than accident under Article 17. Unlike "personal injury" (Article 17), damage need not result from "unusual and unexpected event." Events such as mechanical problems, refusal to unload an aircraft, error in delivering parcels to the consignee, and loss of documentation by the carrier have been taken to constitute "occurrence". ${ }^{125}$ Yet, occurrence must happen (1) while the carrier is in charge of the goods and (2) in an aerodrome or aboard an aircraft. ${ }^{126}$ These two elements which define the duration of liability (i.e. "during

122 Diederiks-Verschoor, supra note 4, p. 106; note however that the majority of commentators appear to be non-assertive about the argument that "personal injury" in the IATA (Montreal) Intercarrier Agreement of 1966 differs in meaning from "wounding and bodily injury" of Article 17 of the Warsaw Convention. For instance, Diederiks-Verschoor, who in her book discusses Krytsal $v$ British Overseas Airways Corp., describes the holding of the American court as "interesting" rather than authoritative. Of course, it must be noted that the Montreal Agreement does not constitute a formal amendment to the Warsaw Convention (see note 32 supra). Yet, other formal amendments to the Warsaw Convention, e.g. the Guatemala City Protocol and the Montreal Protocol No. 3, employ the term "personal injury" in lieu of "wounding and bodily injury". And, the use of the expression personal injury is preferred so as to "signal that [purely] mental injuries have in practice been regarded as included and compensable." (See Cheng, supra note 22, p. 850 ).

${ }^{123}$ The dichotomy between registered and unregistered baggage looks important. First, Article 18(1) mentions only registered baggage. Hence, the carrier is not presumed to be at fault when damage relates to unregistered baggage. Second, as the Convention does not govern the liability of the carrier in respect of destruction, loss or damage to unregistered baggage which the carrier takes charge, it is likely for domestic laws to apply in lieu of the Convention. Incidentally, it must be noted the jurisprudence on this point is diverse (See, e.g., Philipson, supra note 7, § 8.4-8.9).

124 Goods is synonymous with the now widely used term "cargo" and includes almost anything but luggage; see, e.g., Philipson, supra note 7, 8.6.

${ }^{125}$ Diederiks-Verschoor, , supra note 4, p. 81; Philipson, supra note 7, § 8.6

${ }^{126}$ Article 18(2), Warsaw Convention. 
the carriage by air" under Article 18(1)) must exist cumulatively. ${ }^{127}$ This would in essence mean that the Warsaw Convention applies ${ }^{128}$ to damages to luggage and goods occurring during "the airport-to-airport" period save exceptional situations provided in Articles 18(2) and 18(3). ${ }^{129}$

An interesting aspect of the jurisprudence of Article 18, as developed elsewhere, involves the phrase "in charge of the carrier." The carrier is generally understood to be in charge of the goods from the moment they are delivered to it until they are transferred to the custody of the consignee. ${ }^{130}$ The mere absence of physical possession (actual control) does not necessarily relieve the carrier of its duty of care. ${ }^{131}$ In particular, carriers are regarded to be in charge of goods, even if goods are in physical possession of handling agents ${ }^{132}$ and customs officials. ${ }^{133}$

In Mengistu G. $v$ Ethiopian Airlines and Customs \& Excise Tax Administration, ${ }^{134}$ an issue arose whether the handling of cargo to customs officials at Bole International Airport would relieve the carrier from being considered in charge of the goods for the purpose of Article 631 of the Commercial Code, which is identical to Article 18(1) of the Warsaw Convention. The High Court of Addis Ababa agreed with Ethiopian Airlines that

${ }^{127}$ It is not thus enough, for example, to establish that the goods are damaged while in an aerodrome or aboard an aircraft. Claimants must also prove that the carrier was in charge when the damage occurred. See, e.g., Moens, G. \& Gillies, P. (1998) International Trade and Business: Law, Policy and Ethics. Sydney: Cavendish, p.306 [hereinafter Moens \& Gillies].

128 Except in situations stipulated in Article 18(3), domestic law applies where the damage to goods occur outside the airport to airport period; see, e.g., Dempsey, P. (2004) "International Air Cargo \& Baggage Liability and the Tower of Babel" George Washington International Law Review, (36), pp. 283 [hereinafter Dempsey].

${ }^{129}$ Should an aircraft land outside an airport, Article 18(2) extends the application of the Warsaw Convention to loss, destruction or damage sustained at "any place whatsoever". Similarly, Article 18(3) extends the period of carriage by air to any carriage performed outside an aerodrome provided "such a carriage takes place in the performance of a contract for carriage by air, for the purpose of loading, delivery or transhipment." Accordingly, any damage is presumed, subject to proof to the contrary, to have been the result of an event which took place during the carriage by air.

${ }^{130}$ Diederiks-Verschoor, supra note 4, p. 80.

${ }_{131}^{131}$ Moens \& Gillies, supra note 127, p. 306-308.

${ }^{132}$ Ibid.

133 Philipson, supra note 7, $\S 8-18$; but see Hermes Assurance Company v PanAmerican Airways, cited in Diederiks-Verschoor, supra note 4, (p. 81) where an Argentine court held that the good was not in the charge of the carrier where the good was kept in a private storage for the purpose of customs processes.

${ }^{134}$ See note 73 supra. 
the latter's duty to take care of the cargo ended upon the delivery of the goods to customs authority at the airport. On appeal, the Supreme Court confirmed the holding of the lower court on the same point, notwithstanding its simultaneous

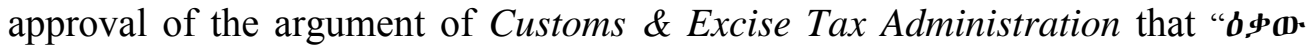

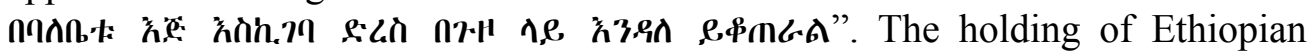
courts that the carrier ceased to be in charge of cargo once it was handed over to customs authorities at the destination airport is incompatible with the contemporary jurisprudence in both civil law and common law members of the Warsaw Convention. ${ }^{135}$

The carrier is liable for delay of passengers, luggage or goods. ${ }^{136}$ However, delay is not defined anywhere in the Convention. According to some authors, ${ }^{137}$ delay "connotes the discrepancy between the time when the carrier should have delivered passengers, baggage or cargo to their destination and the time when it actually did so." As a matter of contract law, the date and time specified in the contract govern any issue involving delay in the performance of contractual obligation. ${ }^{138}$ If no time is agreed, it shall be performed immediately. ${ }^{139}$ Of course, the question "how immediate" poses some problem. Nonetheless, the rules on notice shade some light on the issue. Particularly, Article 1774 of the Civil Code, which entitles a creditor to fix a period of time after the expiry of which he will not accept performance of the contract, stipulates that such period shall be "reasonable having regard to the nature and circumstances of the case." For the carrier to be liable for delay, the time of performance of carriage must therefore be unreasonably late under the circumstances. ${ }^{140}$

${ }^{135}$ Of course, there have been instances where courts elsewhere held the carrier ceased to be in charge of cargo once it was handed over to customs authorities (see note 133 supra). Yet, it is now argued the carrier is regarded as being in charge unless delivery to the consignee takes place. Philipson et al. argue that "the weight of authority in both civil law and common law jurisdictions is now" in favor of the argument that the carrier does not stop being in charge should it hand cargo to customs officials (Philipson, supra note 7, $\S 8-18$ ); see also Moens \& Gillies, supra note 127, p. 308.

${ }^{136}$ Article 19, Warsaw Convention.

${ }^{137}$ Philipson, supra note $7, \S 8-39$.

${ }^{138}$ Article 1756(1), the Civil Code of Ethiopia, 1960, Negarit Gazeta, Proclamation No. $165 / 1960,19^{\text {th }}$ Year, No.2 [hereinafter Civil Code]; incidentally note that neither the Commercial Code's provisions on carriage by air nor the Maritime Code's provision on carriage by sea contain a handy definition of delay that could be analogised.

${ }^{139}$ Ibid, Article 1756(2).

${ }^{140}$ Such construction would be compatible with the jurisprudence elsewhere [see, e.g., Ets Peronny v Ethiopian Airlines, Cour d'Appel de Paris (1975) RFDA 395 (cited in Philipson, supra note 7, $\S 8-44$; Diederiks-Verschoor, supra note 4, p. 95; Moens \& 
Air tickets often include stipulations that times of departure and arrival in timetables are not guaranteed. For instance, Article 9 of Ethiopian Airlines Conditions of Contract stipulates:

"Carrier undertakes to use its best efforts to carry the passenger and baggage with reasonable dispatch. Times shown in timetables or elsewhere are not guaranteed and form no part of this contract. Carrier may...alter or omit stopping places shown on the ticket in case of necessity. Schedules are subject to change without notice. Carrier assumes no responsibility for making connections"

Similar stipulations are common among IATA members. ${ }^{141}$ Yet, courts in numerous jurisdictions have been reluctant to construe contractual stipulations (similar to the one reproduced above) as giving carriers complete free ride with regard to time of performance. ${ }^{142}$ For example, in Ets Peronny $v$ Ethiopian Airlines $^{143}$ the Paris Court of Appeal rendered a clause void in the general conditions of contract that exempted the Ethiopian air carrier from liability for delay. ${ }^{144}$

Gillies, supra note 127, p. 312) where a French court of appeal found the Ethiopian carrier liable for unreasonable delay in the carriage of goods] and the Ethiopian law on carriage of goods by other modes of transport. Within the context of multimodal or land carriage of goods, delay in delivery occurs when (1) the goods have not been delivered within the agreed time or (2) when the goods have not been delivered within reasonable time having regard to the circumstances of the case; see Article 24, Proclamation to Amend Carriage of Goods by Land Proclamation, 2007, Federal Negarit Gazeta, Proclamation No.547, Year 13, No. 58; Article 17(3), Multimodal Transport of Goods Proclamation, 2007, Federal Negarit Gazeta, Proclamation No.548, Year 13, No. 59.

141 Standard conditions of contract produced by IATA are obligatory on member carriers. Yet, the status of IATA "General Conditions of Carriage" vis-à-vis Warsaw Convention and other consumer protection laws are elusive; see, e.g., Philipson, supra note 7, §6-34-6-35 and Diederiks-Verschoor, supra note 4, p. 67.

${ }^{142}$ Note however that conditions of contract in passenger tickets and air waybills would bind passengers in the majority of cases; see, e.g., Philipson, supra note 7, § 14-29; Diederiks-Verschoor, supra note 4, p. 84-85.

${ }^{143}$ See note 139 supra.

${ }^{144}$ The first decade of the $21^{\text {st }}$ century witnessed aggressive legislative efforts to protect air passengers from airline malpractices. In particular, the USA and EU (European Union) are in the driving sit in enacting consumer protection laws that strengthen passenger rights regarding, for instance, tarmac delay and cancellation of flights; see, e.g. EC Regulation 261/2004, "establishing common rules on compensation and assistance to passengers in the event of denied boarding and of cancellation or long delay of flights, and repealing Regulation (EEC) No 295/91", Official Journal of the European Union and US Department of Transportation's Final Rule and Summary, (available at $<w w w . r e g u l a t i o n s . g o v>$, docket DOT-OST-2010-0140 $\left(21^{\text {st }}\right.$ April, 2011). As far as Ethiopia is concerned, there is no specific legislative 


\section{2- Limitation of the Carrier's Liability}

One of the cardinal principles of the Warsaw Convention is limitation of air carriers' liability. The principle is embodied in Article 22 and applies in the majority of cases. There are however exceptional circumstances that justify the non-observance of the limits, hence unlimited liability of the carrier. Meanwhile, the carrier may totally avoid liability under the cases provided in Articles 20-21. ${ }^{145}$ For the sake of succinctness, however, we will only deal with Article 22 and the interesting topic of breaking the limit.

According to the original Warsaw rule on limitation of liability, the carrier's liability for death or injury of passengers is limited to the sum of 125,000 French gold francs unless a higher limit of liability is agreed by the parties. ${ }^{146}$ Moreover, liability for damage or loss of checked baggage and of goods is limited to 250 French gold francs per kilogram. ${ }^{147}$ As regards objects of which the passenger himself takes charge, the liability of the carrier is limited to 5,000 francs per passenger. ${ }^{148}$

Ever since the coming into force of the 1975 Montreal Protocols, the liability caps are expressed in Special Drawing Rights. ${ }^{149}$ Accordingly, the liability of a carrier for death, wounding or bodily injury is restricted to 8,300 SDRs (or its equivalent in Birr at the date of the judgement). ${ }^{150}$ As regards objects of which passengers take charge themselves, the liability cap is now 332 SDRs per passenger. ${ }^{151}$ The Montreal Additional Protocol No. 1 limits the liability of the carrier in the carriage of baggage or cargo to 17 SDRs per kilogram. ${ }^{152}$ The fact that Ethiopia is a member to the Montreal Additional Protocol No. 4 renders the

movement in that direction. Yet, the new Trade Practice and Consumers' Protection Proclamation would hopefully play a limited role in protecting passengers and other consumers alike from the vices of adhesion contracts and other business malpractices; see, e.g., Article 22 and 29, Trade Practice and Consumers' Protection Proclamation, 2010, Federal Negarit Gazeta, Proclamation No. 685, Year 16, No. 49. See also Article 1738 Civil Code.

${ }^{145}$ See Philipson, supra note 7, $\S 9-01-9-63$ for a fair discussion on Articles 20-21, Warsaw Convention and the jurisprudence thereto.

${ }^{146}$ Article 22(1), Warsaw Convention.

${ }^{147}$ Ibid, Article 22(2).

${ }^{148} I d$, Article 22(3).

${ }^{149}$ See note 39 supra and the accompanying texts.

${ }^{150}$ Article II, Montreal Protocol No. 1.

${ }^{151}$ Ibid.

${ }^{152} I d$. 
liability limit in the carriage of cargo inviolable unless the consignor opts for a higher limit by paying a supplementary sum. ${ }^{153}$

As seen earlier, the 1966 Montreal Intercarrier Agreement binds Ethiopian Airlines to a higher [than the Warsaw system affords] limitation cap with regard to damages sustained on a journey to, from, or with an agreed stopping place in the United States of America. ${ }^{154}$ This higher limitation cap is U.S. $\$ 75,000.00$ inclusive of legal fees and costs. ${ }^{155}$

Obviously, the limitation cap varies with the applicable convention or agreement. For instance, the claims of a passenger who flies Ethiopian from Washington DC to Addis Ababa would be subject to the US \$ 75,000 limit. ${ }^{156} \mathrm{~A}$ passenger on a flight from Addis Ababa to Dar es Salaam would have his contract of carriage subject to the $125,000.00$ francs (or 8,300.00 SDRs) limit under the original Warsaw Convention. ${ }^{157}$ On the other hand, the claims of a passenger, with a round trip to Nairobi-Addis Ababa-Nairobi ticket, would be subject to the 250,000 francs (or 16,600 SDRs) as Kenyan courts apply the Warsaw Convention as amended by the 1955 Hague Protocol. ${ }^{158}$ Finally, the contracts of passengers in the same flight would be subject to different liability limits. ${ }^{159}$

${ }^{153}$ Article VII, Montreal Protocol No. 4. Also, note that this protocol does away with the principle of rebuttable presumed fault with regard to carriage of cargo, save in cases of delay and contributory negligence (see Articles V-VI). Put in other words, the carrier cannot rely on the defences of "all necessary measures" or "impossibility" which were possible under the original Warsaw rules.

${ }^{154}$ See notes 30 and 38 supra.

155 The limit is US \$58,000.00 exclusive of legal fees and costs; see Advice to International Passengers on Limitation of Liability, note 38 supra.

${ }^{156}$ Ibid.

${ }^{157}$ This is because both Ethiopia and Tanzania are High Contracting Parties to the original Warsaw Convention; see the list of ratifications from $<$ http://www.icao.int/icao/en/leb/wc-hp.pdf $>$.

${ }^{158}$ Ibid; note however that the liability of the carrier would be limited to the original Warsaw cap, i.e., 8,300.00 SDRs if the passenger was with a one way Nairobi Addis Ababa or round trip Addis Ababa - Nairobi - Addis Ababa ticket. This is because Ethiopian courts would assume jurisdiction as they are the courts of the place of destination; and they would most likely apply the Warsaw Convention (unamended by the Hague Protocol) for it is the common treaty in force between Kenya and Ethiopia.

159 See, e.g., Lowenfeld \& Mendelsohn, supra note 28, p. 524-526; Cheng Chua, J. (2003) "Breaking Convention: When is a Carrier's Limit of Liability under the Warsaw Convention Broken? Beyond Beryl Claire Clarke \& Ors v Silkair (Singapore) Pte Ltd" Singapore Academy Law Journal, (15), p.7. 
The pro-carrier principle of limitation of liability, which may get in the way of unlimited settlement of damages, may be challenged in exceptional circumstances. One $\operatorname{such}^{160}$ circumstance involves the concept of wilful misconduct. An international air carrier loses its right to limit or exclude liability should damage (to passenger or goods) result from its or its agent's wilful misconduct. ${ }^{161}$ Moreover, the carrier is prohibited from relying on the provisions of the Convention limiting or excluding liability when the damage is the result of default which, in accordance with the law of the court entertaining the case, is considered to be equivalent to wilful misconduct. ${ }^{162}$

Wilful misconduct is an English translation of "dol" in the original and authentic French version of Article 25 of the Convention. There are however arguments that the term 'wilful misconduct' does not accurately represent the French concept of "dol." According to a leading author in international air law, "dol" refers to "the intention to inflict specific injury on another person."163 In contrast, wilful misconduct does not necessarily imply the intention to inflict injury. ${ }^{164}$ As a result, jurisdictions that rely on the English version of the Convention apparently apply Article 25 in a wider context than those relying on the French version. ${ }^{165}$

${ }^{160}$ It is also possible to break the limit by establishing that (1) the carriage is not international, (2) no ticket is issued and (3) no adequate warning was given; see, e.g., Kennelly, J. (1975-76) "Aviation Law; International Air Travel - A Brief Diagnosis and Prognosis" California Western International Law Journal, (6), p. 105-106.

${ }^{161}$ Article 25, Warsaw Convention.

${ }^{162}$ Ibid.

${ }^{163}$ Diederiks-Verschoor, supra note 4, p. 96.

$164 \mathrm{Ibid}$; see also examples of wilful misconduct from common law jurisdictions in Moens \& Gillies, supra note 127, p. 310-311 and Philipson, supra note 7, § 10-19 et seq.

165 Id; note however that Article 25 allows courts to assimilate "dol" with "faute équivalente au dol" (default equivalent to wilful misconduct) if the later concept exists in their legal system. This for example guarantees the application in jurisdictions like France of Article 25 to cases involving gross negligence. This would presumably reduce instances of divergent interpretation of Article 25. Yet, problems still exist as the French version of "faute équivalente au dol" may not always be equivalent with wilful misconduct as developed in Anglo-American jurisdictions. Besides, it should also be noted that the jurisprudence of wilful misconduct has not always been consistent in jurisdictions which use identical versions of the Warsaw Convention; see also Mankiewicz, supra note 24,p. 738; Moens \& Gillies, supra note 127, p. 311; Philipson, supra note 7, § 10-10; Guerreri, G. (1959-1960) "Wilful Misconduct in the Warsaw Convention: A Stumbling Block" McGill Law Journal, (6), p. 267 et seq. 
To avoid the divergent interpretation of Article 25 and hence the instance of forum shopping, Article 25 was amended in the 1955 Hague Protocol. Accordingly, Article 25 (as amended) reads: "the limits of liability specified in Article 22 shall not apply, if it is proved that the damage resulted from an act or omission of the carrier, his servants or agents, done with intent to cause damage or recklessly and with knowledge that damage would probably result..."166 Apart from the fact that "omission"167 has now been included as a ground of unlimited liability, the new Article 25 is different from its predecessor in its simultaneous use of both "dol" and "wilful misconduct". ${ }^{168}$

Articles XV cum IX of the Montreal Protocol No. 4 imply that the concept of wilful misconduct has given way to the principle of absolute carrier liability for cargo claims. Yet, Article 25 of the Warsaw Convention still forms part of the Ethiopian law on international air carriage of passengers and baggage. As a result, Ethiopian courts could still be dragged to the question involving the exact scope of the original Article 25. It is however the opinion of this author that Ethiopian courts would (and should) prefer the English concept of wilful misconduct over the French concept of "dol" as the English version of the Convention along with the accompanying literature are easily accessible than the official French version.

As seen above, Article 25 applies when the carrier inflicts damage either intentionally or recklessly (acting with knowledge but without regard for the consequences). ${ }^{169}$ Courts in English speaking countries found wilful misconduct when for example the pilot descended to a level below the flight altitude he had been instructed to maintain ${ }^{170}$; the pilot failed to climb to the level he had been instructed and as a result the aircraft crashed into a mountain ${ }^{171}$; the aircraft is

${ }^{166}$ Article XIII, Hague Protocol.

${ }^{167}$ See note 112 supra and the accompanying text for a related controversial issue of whether inaction constitutes accident for the purpose of Article 17.

168 Despite this, the Hague Protocol has not completely solved the problems of interpreting Article 25. According to Moens \& Gillies, "the amended Article 25 has produced as many problems of interpretation as its predecessor." (See Moens \& Gillies, supra note 127, p.310). The problems of interpretation of the amended Article 25 are however beyond the scope of this article as Ethiopia is not a party to the Hague Protocol.

169 Diederiks-Verschoor, supra note 4, p. 96; In Re Korean Airlines Disaster, 704 F. Supp. 1135 (D.D.C. 1988) cited in Gesell \& Dempsey, supra note 28, p. 861-862; Horobin v BOAC, 2 All English Report 1016(1952) cited in Philipson, supra note 7, $\S 10-23$.

${ }^{170}$ Berner v British Commonwealth Pacific Airlines Ltd, 346 F2d 532 (1963) cited in Philipson, Ibid, § 10-34.

${ }^{171}$ Ritts v American Overseas Airlines (1949) US Av 65cited in Philipson, Ibid, § 1034. 
inadequately equipped; ${ }^{172}$ and when the pilot decided to navigate notwithstanding unreliable INS (Inertia Navigation System). ${ }^{173}$

The establishment of wilful misconduct prohibits the carrier from availing itself of provisions limiting or excluding liability. ${ }^{174}$ These provisions certainly include Articles 20 and $22 .{ }^{175}$ It is not, however, a matter of consensus whether a carrier, guilty of wilful misconduct, is excluded from relying on, for example, Article 26(4) ${ }^{176}$ It is to be noted that the importance of wilful misconduct is declining in modern private international air law where the principle of absolute liability reigns. ${ }^{177}$

\section{Concluding Remarks}

Despite its long history, the Ethiopian law on international air carriage appears to have been neglected and has not attracted the attention of practicing and academic lawyers for decades. It is also sad that Ethiopian courts apply the inappropriate law (in the examples mentioned above) when dealing with matters of international air carriage. It is, however, hoped that the Civil Aviation Proclamation, which lays the ground for wider utility of the Warsaw Convention (and some of its amendments), will not remain unnoticed. The author is of the opinion that Ethiopian courts would benefit from foreign jurisprudence and local literature in their attempt to interpret and apply the 1929 Warsaw Convention and its Montreal Additional Protocols - which are now the main source of Ethiopian law on carriage by air.

This short introduction to the Ethiopian law on carriage by air reveals that the Warsaw Convention governs the liability of any air carrier. The carrier assumes fault based liability for injury and death of passengers, loss or damage to luggage and goods, and delay. The carrier may escape liability in cases provided under Articles 20-21. Otherwise, the liability of the carrier is limited to the amount indicated under Article 22 of the Warsaw Convention save in exceptional circumstances involving, for example, wilful misconduct. Claims related to carriage by air may be brought before an Ethiopian court where the

172 Philipson, Ibid, § 10-35.

173 In Re Korean Airlines Disaster, note 169 supra.

${ }_{175}^{174}$ Article 25(1), Warsaw Convention.

${ }^{175}$ Article 22 limits the carrier's liability; whereas, Article 20 relieves the carrier from liability subject to proof of "all necessary measures" and "contributory negligence."

176 Philipson, supra note 7, § 10-16.

177 The Montreal Protocol No. 4 as well as the Montreal Convention represent modern international laws on carriage by air that do away with the concept of wilful misconduct. Within the context of Montreal Convention, the concept of wilful misconduct, rather "negligence or other wrongful act or omission", now plays a reduced role; see Article 21, Montreal Convention. 
carrier keeps its residence, principal place of business or establishment. Ethiopian courts may also entertain air carriage cases where Ethiopia is the place of destination.

That said, legislative response to contemporary developments in the air business is desirable. In particular, the drawbacks of the Warsaw Convention ought to be addressed with a view to updating the various stipulations with current needs, events and realities. A case in point is the need to balance the elements of the pro-carrier regime with pro-passenger or pro-cargo-owner principles. Of course, due care should also be taken not to seriously undermine the Ethiopian aviation sector. Yet, there is the need to raise the limitation cap for personal and cargo damages instead of introducing absolute carrier liability. Secondly, rules on the form and content of passenger and luggage tickets must be simplified to accommodate developments in the air business. And thirdly rules of jurisdiction must be updated so that Ethiopian residents may bring actions against foreign air carriers before Ethiopian courts. Admittedly, however, there is no easy way to do this. Should Ethiopia join either the 1955 Hague Protocol or the 1999 Montreal Convention, at least two of the three courses of action can materialize in a manner that strikes a balance between the interests of passengers, cargo owners and air carriers. 